\title{
Inward investment into the European hotel investment market
}

Received: 28 April 2004

\section{Simon Allison}

is President of Europe for Millennium \& Copthorne Hotels plc, a listed company based in London which is one of the largest owners and operators of upscale hotels in the world. Simon's responsibilities include all aspects of operations, sales and marketing and development within the region. Prior to joining M\&C this year, Simon was Managing Director of the European operations of Molinaro Koger, a major and fastgrowing hotel real estate advisor. Before that, he served as Chief Financial Officer of Hospitality Europe, a specialist owner of upscale hotels, during its successful expansion. His career began with ten years as an investment banker at JP Morgan after graduating from Oxford University.

\section{Abstract}

This paper looks at the patterns of inward investment into the heavily-fragmented European hotel sector. It notes that there have been relatively fewer transactions than one might expect, given the globalisation of the industry. This is largely because overseas buyers are also small companies, often split (eg in the US markets) between real estate owners and management companies. They are often discouraged from corporate acquisitions by the complexity of doing deals in Europe's often impenetrable markets and the heavy property portfolios of most European players. Moreover, at the luxury/upscale ends of the market there are few independent players left to acquire. In terms of single-asset acquisitions, there has been a diversity of buyers, largely driven by capital availability in their home markets - Middle Eastern money in the 1970s, Japanese in the 1980 and US and South-East Asian in the 1990s. As with corporate deals, low yields and complexity have deterred many investors, especially those from the USA who are used to dealing in only one jurisdiction. In the future, the only certainty is change. New buyers are perhaps most likely to come from the emerging economies - China, India and Russia - while new ownership structures such as the spread of European REITs may attract larger numbers of institutional buyers. This in turn may produce a greater standardisation of brands and products, as these investors seek greater certainty, leading to a more predictable

Simon Allison

Millennium \& Copthorne Hotels plc Corporate Headquarters

Scarsdale Place

Kensington

London W8 5 SR

Tel: +44 (o) 2078722450

Fax: +44 (o) 2078722456

E-mail: simon.allison@mill-cop.com investment market - but probably also a more boring hotel experience for guests.

\section{Keywords:}

fragmentation, globalisation, impenetrable markets, diversity, change 
Industry fragmentation

\section{INTRODUCTION}

As many readers of this paper will already know, the hotel industry is desperately fragmented. While several of its larger brands, like Hilton or Holiday Inn, are truly international and known to the general public, the industry has thrown up no major global corporation like BP, Vodafone, Coca-Cola or Citibank. Indeed, the largest hotel companies by market capitalisation, like Marriott International, Hilton Hotels Corp., Accor and InterContinental, all have a value of less than $\$ 15 \mathrm{bn}$ - tiny by multinational corporation standards.

The same story applies to Europe - the combined market value of InterContinental Hotels Group, Sol Melia, Hilton Group, Accor, $\mathrm{NH}$, Whitbread and Millennium \& Copthorne, at $€ 24.2 \mathrm{bn}$ as at 11 March 2004, was only 25 per cent of that of Coca-Cola. ${ }^{1}$

The small scale of the industry has specific implications for investors, including inward ones. First, there are lots of affordable targets. A single mid-market hotel of, for example 200 rooms, priced at $€ 100,000$ per room, would cost $€ 20 \mathrm{~m}$, of which anything from 55- 85 per cent can be debt-financed, depending on the degree of leverage and the type of operating arrangement. For a normal European transaction, loan to values are in the $65-70$ per cent range. ${ }^{2}$ As a result, it is perfectly possible for an investor to buy a sizeable hotel for an equity investment of $€ 5-10 \mathrm{~m}$.

Even relatively significant hotel sector deals, for example, the takeover of the Savoy group by Quinlan Private for $£ 750 \mathrm{~m},{ }^{3}$ or of Forte by Granada for $£ 5.3 \mathrm{bn},{ }^{4}$ are not large transactions by global standards.

With targets forming easy bite-sized pieces, the degree of crossborder investment might be expected to be considerable, especially as hotel groups - at least those aimed at the top end of the market - tend to market to a global traveller and therefore need a global presence. But just as targets are small, so too are investors themselves. Or, to put it another way, while the market capitalisation of the seven European majors was $€ 24.2 \mathrm{bn}$ in March 2004, that of the larger American groups (Marriott International, Starwood, Hilton, Host Marriott, Four Seasons, Fairmont and Extended Stay America) was only $€ 28.5 \mathrm{bn}$, or 18 per cent larger. ${ }^{5}$

A final theoretical point to note is that the industry itself is not small. There are probably somewhere in the range of 15 million hotel rooms in the world, with a total value of up to approximately (and it is a very approximate estimate) $\$ 1,200 \mathrm{bn} .^{6}$ That is leaving aside the value of the management and branding of hotels on which most of the larger and better-known hotel companies focus.

\section{THE CURRENT SITUATION}

The reasons why such a large industry has produced so few big companies are the fragmentation between franchising, managing and owning, and in turn the fact that ownership is so widely dispersed. Moreover, while a few corporations and financial 


\section{Inward investment theory}

\section{Lack of foreign acquirers}

institutions now specialise in acquiring and asset-managing hotels, the majority of European hotel stock still resides in family hands. ${ }^{7}$ From time to time these assets come on to the market, but in general families like to keep hold of their family business or, alternatively, have price expectations way above economic reality. While many investors claim to be looking for under-managed, unbranded and under-renovated family hotels, the reality is that not very many of these actually become available in Europe in any given year.

These patterns could lead one to draw the following theoretical conclusions about how inward investment might work.

- There will be a lot of smaller transactions.

- Few larger European companies will be bought, because few other hotel groups have the resources to pay for them.

- Buyers from outside the industry, such as property groups and financial investors, will be in evidence.

- Many non-European buyers end up buying from other nonEuropean owners and rarely succeed in plucking familycontrolled hotels.

Not surprisingly, these are more or less the exact patterns that one sees in practice.

If one looks at corporate transactions, it is clear that none of the biggest European players has been subject to an acquisition from outside the continent; and even among the smaller ones, acquisitions by other hotel groups have been rare. Despite frequent rumours to the contrary, none of the continents' top groups Accor, NH, Whitbread, Sol, InterContinental and Hilton - has been taken over from outside Europe (or inside Europe either, for that matter). On the other hand, overseas institutional investors can always buy shares in the market and gain exposure that way.

The largest European hotel M\&A deal was the takeover of Forte by Granada in 1996 for $£ 5.3 \mathrm{bn}$ including debt, ${ }^{8}$ but it was an allBritish affair. Some other large UK hotel groups have been bought by non-Europeans, such as Thistle's takeover by BIL, Meridien's acquisition by Terra Firma/Nomura and Savoy's purchase by Blackstone - and far earlier, in 1988, InterContinental's takeover by Japanese retail group Seibu Saison - but none of these buyers constituted a rival hotel group.

In fact if one looks at the larger US hotel companies like Hilton Hotels, Marriott International and Starwood, none has bought a major European company, although Starwood may be coming close with Meridien, and its predecessor, ITT Sheraton, did acquire Ciga in 1995. Apart from that deal, one has to go significantly down the size scale to find transactions where non-European hotel groups have bought European ones. Examples would include Raffles' purchase of Swissotel, CDL's buy-out of Copthorne, Patriot American's deal with Arcadian and the collection of smaller but savvy deals wrought by Westmont in France and Italy in the early 1990s. 


\section{Globalisers avoid real estate}

\section{European majors have a diverse business mix}

So, overall, European deals have been dominated by Europeans. What is the explanation for this pattern? There are a number of answers.

\section{US groups are not heavily capitalised but are heavily branded}

Most of the more prominent US hotel groups are asset-light. Some, like Cendant and Choice, are essentially franchisors; others like Marriott International are pure managers; while other companies such as Hilton or Starwood have their earnings buoyed by a few landmark hotels, but otherwise focus on management contracts. While these groups are often in the race for major European acquisition targets like Meridien or InterContinental, they usually lose for what the author believes to be a combination of reasons. First, the targets are large enough to have a major (and in the short term, potentially negative) impact on their financial results, and the price levels may seem to compare unfavourably with what they can secure at home. To keep the deal size down, they also often team up with financial or property partners - but that provides significant deal friction, with time spent on structuring and negotiating. Finally, the major US branded groups are generally unwilling to pay a material brand premium when they already own globally recognised marques of their own.

\section{European groups are often integrated and have more firepower}

In contrast to the US groups, European hotel companies have often been part of a larger-scale enterprise with the firepower to make significant acquisitions. Specifically, many of them are linked together with highly cash-generative businesses which provide succour in the cyclical hotel downturns and also allow the groups to secure bank debt in a hurry - very useful in the acquisitions game. Thus, Bass for many years linked hotels with brewing and pubs; Hilton combines a strong gaming element with its hospitality portfolio; and even Accor has a significant cash cow in its voucher business. $^{9}$

\section{Asian buyers will not pay for brands either}

Most Asian buyers - like their American counterparts - will not bid up for hotel brands, but for very different motives. Asian buyers generally have a property background, whether they be Great Eagle in Hong Kong, CDL, the Government Investment Corporation in Singapore or Landmark in Thailand. These buyers are understood to be unattracted by the intangible nature of brands and so tend not to be competitive bidders in auctions where the name is a significant element of the value.

\section{Most European targets are domestically oriented}

Apart from the largest brands, many European hotel groups are in 


\section{Middle market not globalised}

\section{Scenarios for inward investment acquisitions}

the three-four-star range and focus their attentions on domestic or regional - but not global - travellers. Examples include groups like De Vere and Macdonald in the UK; NH and AC in Spain; Jolly and Starhotels in Italy; and Steigenberger and Maritim in Germany.

Most international hotel groups seek access to international travellers and aim to expand their networks to appeal to airborne businessmen who usually visit capital cities and financial centres. Acquisition of a mid-market chain, represented in smaller towns and appealing to car-borne travellers, is often not appealing to these groups.

Moreover, the most developed mid-market hotel chains outside Europe are all in the USA and are all franchise-based. Since these domestic European chains are generally owner-operators with value heavily concentrated in real estate, they are not appropriate acquisition targets for the US franchise groups, which will not invest in property-heavy companies.

While no one of these factors has had an overwhelming impact on the acquisition process, taken together they may provide at least some explanation for the relative paucity of corporate-level inward investment into European hotels.

\section{THE FUTURE FOR CORPORATE DEALS}

Whether any of this will change in the future is hard to say. In order for it to change, one would need to see hotel groups from either Asia or the USA deciding to make corporate deals in Europe. One could look at two main scenarios:

- Upscale groups acquiring four- and five-star chains

- Midscale groups targeting the mid-market.

It is hard to believe that the former scenario will occur because, in reality, targets are few and far between. Meridien may yet go to Starwood but, after that, there are precious few upscale groups left. A non-comprehensive list might include the following:

- Kempinski — has resisted all blandishments

- Corinthia - has been blighted by the US sanctions on its Libyan shareholders but may yet be revived now these are reversed

- Rezidor - tie to Radisson is offputting for other branded groups

- Boscolo - growing not shrinking

- Maritim and Rocco Forte hotels - remain resolutely in family hands

- Steigenberger - often rumoured to be for sale but never actually sold.

Since deals are largely opportunity-driven in this sector, it is 


\section{Potential for mid- scale deals}

\section{South-East Asian recovery}

\section{Potential for single asset deals}

\section{Money created acquirers}

therefore unlikely that there will be a spate of upscale corporate transactions.

The mid-market sector may be more interesting. Certainly, in the UK there are effective ongoing sales of assets from many midmarket companies, such as Queen's Moat House, which is in the public domain, and others which are not, comprising in total a major segment of the three-four-star sector. The plethora of midscale start-ups in Spain may also lead to some corporate sales in the next five years, especially in the light of overbuilding in cities like Madrid, where it is predicted by Reuters that supply will increase by 20 per cent in the next two years. ${ }^{10}$ With these levels of supply, some hoteliers are likely to come under pressure.

Moreover, there may be more non-European buyers emerging. Groups like Westmont Hospitality, which were major deal-doers in the 1990s, are again believed to be looking for stock, and some of the US pure management groups like Interstate and Harrell Hospitality may also seek to grow US operations. Harrell recently announced its intention to expand Marriott's Courtyard brand in the UK. ${ }^{11}$ Some US REITs (real estate investment trusts) like CNL have also begun to consider expanding into Europe.

The South-East Asian markets are also recovering and, with many of the upscale Asian groups (for example, Taj, Peninsula and Shangri-La) still lacking a meaningful European presence, some of the luxury transactions may also get unlocked.

\section{SINGLE ASSETS}

So much for corporate deals. What about single assets? Here the picture has been much more varied, and seems to be influenced as much as anything else by capital availability at least in as far as there is a correlation between capital availability and transactions. Each of the last few decades has seen 'waves' of investment coming into European hotels, and in each case it was on the back of a booming economy in the international investors' home regions.

- In the 1970s it was Middle Eastern money that dominated in the wake of sharp increases in oil prices which provided previously undreamed of wealth to regional magnates.

- In the 1980s, Japanese and then to a lesser degree Swedish capital flowed outwards based on economic strength and liberalising investment regimes.

- In the 1990s, South-East Asian (mainly Thai and Singaporean) capital flowed, again on the back of the strengths of the 'tiger economies' - a trend which came to an abrupt halt in 1997. Another feature of the last decade was the emergence of significant US opportunity fund money, as US institutions globalised their portfolios.

- In recent years it is British, Irish and German financial institutions which have set the pace, most notably in portfolio sale-leasebacks, with non-European buyers lagging significantly behind. 
Perhaps it is possible to hope that the next decade will see heavy investment by Russian oligarchs and maybe emerging Chinese multinationals - but that remains to be seen.

\section{BUYER MOTIVATIONS}

While there is a clear correlation between capital availability and investment, the actual motives of buyers have been far more diverse. One can examine each group in turn.

There is no question that Middle Eastern and other oil-wealthbased buyers focused on upscale assets and in at least some cases they could be called 'trophy' buyers, acquiring luxury hotels at high prices without any long-term strategic motive to develop a hotel business. Such assets tended to be in the key cities where Middle Eastern demand was focused - London, Paris and to a significantly lesser extent destinations like the south of France and Geneva. Examples include the Sheraton Park Tower and Carlton Tower hotels in London, the InterContinental in Geneva and the Prince de Galles in Paris.

Japanese capital flowed more widely, in some cases following Japanese hotel brands like Nikko and ANA, but also focused on major European business destinations, with London high on the agenda alongside other global financial capitals. Thus, Nikko acquired hotels in Paris, London and Dusseldorf; ANA in Vienna; Seibu Saison bought the entire InterContinental chain; and Japanese interests linked to the Sanwa conglomerate owned (until recently) the Marriotts in Munich and London's Grosvenor Square.

Initially, South-East Asian capital generally followed the same pattern, with groups like CDL from Singapore and Landmark in Thailand buying multiple properties in London. But over time money from this region has also flowed into continental Europe, with deals like Raffles' purchase of the Vier Jahreszeiten in Hamburg and subsequently of Swissotel, GIC's investment in the InterContinental in Prague, Dusit Thani's (at least initially) ill-fated purchase of Kempinski and the Dorchester Group's acquisition of the Principe di Savoia in Milan and Meurice and Plaza Athenee in Paris.

Taking advantage of the lack of specialist hotel ownership companies, US opportunity funds became a major factor in European hotel transactions in the 1990s and have proved adventurous. In most cases, acquisitions of hotels and portfolios have been made within corporate structures. Goldman Sachs' various Whitehall funds have invested in Strategic Hotel Capital to buy hotels in Paris, Hamburg and Prague and, with Westmont, to acquire midscale portfolios across much of Western Europe.

Blackstone is currently in significant acquisition mode, buying in Germany through its investment in Event Holding; and in the late 1990s it also acquired a significant European portfolio along with Accor and Colony Capital. Other US investors became major shareholders in the specialist hotel-owning company, Hospitality Europe, which took its portfolio from two to eight continental 


\section{Europe remains relatively impenetrable}

European hotels during the late 1990s. More recently, Duke Street Capital's acquisition of the one-star Galaxie portfolio in France shows that overseas money is willing to go into the budget sector as well as more established hotel products.

With an aggressive view of risk and reward, these US opportunity fund groups have tended to be investors earlier in the cycle than more institutional investors - but they also need a single-cycle exit to secure the 20 per cent plus rates of return they seek. In the late 1990s as growth slowed and lower-cost capital emerged, there was a hiatus in foreign investment. German funds, able to acquire leased hotels at yields of 5-6 per cent, and UK property groups which bought turnover-based leases on cap rates of 7 per cent or less, pushed out the non-European buyers to a significant degree in the 1999-2002 period. But as results crashed in the wake of 9/11, the Gulf War, SARS and (most importantly) the economic downturn, more and more hotels have lacked the earnings required for a lease-based solution. This is bringing back the more aggressive, upturn-oriented buyers once again.

\section{BARRIERS TO FOREIGN ENTRY}

While statistics are hard to come by, it is still likely that the overwhelming majority of European hotels are owned by Europeans. Many foreign groups still encounter a range of barriers to entry into the markets.

\section{Initial yields}

Top-level European hotels are often offered by sellers at yields of only slightly more than the cost of debt - say 7 per cent for a managed property, where the buyer will take the operating risk. For US investors, in particular, who are accustomed to double-digit yields, this is often a disincentive.

\section{Tax}

Cross-border investment in Europe inevitably necessitates dealing with multiple tax regimes. While many countries, notably the Netherlands and Luxembourg, have investor-friendly regimes, the additional complexity is another disincentive for foreign investors, especially Americans used to dealing with only one jurisdiction.

\section{Regulations}

In addition to tax issues, every European regime faces additional constraints, whether it be the need for a meat-chopping licence in Germany, limits to the rates of interest that can be charged in France, or enormous redundancy costs in Belgium. Getting used to these - alongside the need to transact in a foreign language - can be offputting for investors venturing out of their home jurisdictions for the first time, as well as adding time and cost to the due diligence process. 


\section{The only certainty is change}

\section{Lack of deal transparency}

Compared to other regions (again, particularly the USA), there are relatively few hotel deals and these are not as widely documented or publicised. Knowing what constitutes a true 'comparable' transaction is difficult.

\section{THE FUTURE FOR ASSET DEALS}

Looking ahead, it is difficult to see many of these obstacles falling away. Despite EU moves towards harmonisation, local regulations and tax regimes will continue to differ. Entry barriers are unlikely to change in cities like Amsterdam and Rome, where historic centres preclude significant new development, and the presence of these entry barriers will mean that yields remain low.

Transparency at least may increase, particularly if REIT structures take hold across Europe, increasing institutional participation in the hotel real estate sector. This in turn may encourage greater non-European intervention in the sector as global portfolio investors are attracted in by the more institutional nature of the estate.

Over the longer term the potential for non-European investment is very great. Rapid development of the Gulf tourism markets like Dubai and Qatar - could lead to a new wave of wellcapitalised hotel industry investors; the gradual recovery of SouthEast Asian economies may stimulate investment from there; and, eventually, acquisitions of hotels by Chinese and Indian investors seeking to tap into their outward-bound markets could be very substantial.

\section{CONCLUSION}

In a highly fragmented industry like the hotel sector, inward investment is also fragmented, taking many forms and being derived from many sources. Patterns are fairly difficult to identify and predictions are hard to make. It is clear, however, that, while intermittent and generally small-scale, inward investment has played a significant role in the industry, at both the corporate and the single-asset levels. There is no reason to believe that this will change - indeed, in a globalising world, it may speed up.

What may well change, however, is the source of the inward capital. In part this will be due to alterations in the boom/bust pattern in different countries; in part to the liberalising of external investment rules; in part, perhaps, to the expansion of new hotel groups (especially Asian) with investor capital 'following the flag'. Exchange rate movements will also, inevitably, have an impact. Thus in the near term, the Asian recovery and weak dollar may favour Eastern groups - but this could just as easily be reversed in the longer term.

Structures of investment are also probably going to change as the creation of hotel-specific property vehicles, either in the form of REITs or pportunity funds, spurs greater institutional 
investment in the sector and the continuing separation of bricks and brains.

Finally, as the power of global brands increases, so more smaller groups will be swallowed up by the larger - generally US and UK - multinational branded operators whose economies of scale in the form of loyalty programmes, corporate relationships, brand recognition, training and promotion opportunities and purchasing power slowly but steadily erode their domestic competitors.

A more diverse world investor will emerge, therefore, but not necessarily a more diverse range of choices for the hotel user, and not necessarily a more interesting investment market. With the onset of the standardisation so beloved by global investors, the quirks and the opportunities to discover hidden jewels in European hotel investment undoubtedly will be reduced, probably forever.

\section{References}

1. Morgan Stanley (2004) Leisure and Hotels Weekly, 12 March; and ft.com.

2. Bartl, H. and DiBenedetto, R. (2003) 'Capital for an embattled industry: How hotel investors can tap into the debt market', Journal of Retail and Leisure Property, Vol. 3, No. 3, pp. 247-259.

3. See http://thescotsman.scotsman.com/business.cfm?id $=411472004$.

4. Financial Times, 29 May 2001.

5. Ibid.

6. Teerapittaysapaisan, S. (2002) 'What impact has the globalisation of hotel management companies had on European hotel ownership trends?', unpublished MBA Dissertation, Royal Holloway, University of London, England.

7. Ibid.

8. Financial Times, 29 May 2001.

9. Company Annual Reports.

10. Daily Lodging Report (2004) dailylodging@ix.netcom.com, 31 March.

11. www.hotel-online.com?News/2004_Mar_25/p.4421080321197.html. 